\title{
NUMBERS AND NEST SITE \\ CHARACTERISTICS OF THE PIPING \\ PLOVER IN CENTRAL ALBERTA, 1974-1977.
}

D. V. CHIP WESELOH and LINDA MCKEANE WESELOH, Canadian Wildlife Service, Canada Centre for Inland Waters, Box 5050, Burlington, Ontario. L7R 4A6

The Piping Plover is classified as a sensitive, threatened or endangered species across most of North America. 23591415 Recently, surveys and studies have been conducted in an attempt to determine the distribution and size of the remaining populations. ${ }^{57} 1418$ The breeding distribution of the Piping Plover is limited to the Great Plains, the Great Lakes and the Atlantic Coast of North America. ${ }^{41}$ The populations on the Great Lakes and the Atlantic Coast have decreased markedly in recent years. ${ }^{78}{ }^{12}$ On the Great Plains, the Piping Plover's status is less well known. Only in Saskatchewan has there been a recent evaluation. ${ }^{17} 18$ There, Renaud concluded that some local decreases had occurred, but the population was not showing signs of a general decline. ${ }^{18}$

Aside from a general species account, the status of the Piping Plover has not been investigated in Alberta, where it has been known to breed since at least 1930 but only in the central part of the province. ${ }^{102122}$ Between 1974 and 1977, Piping Plovers were censused at selected areas in central Alberta and limited data collected on nest site characteristics from a single "colony". This report documents the results of those investigations and, based on data from other sites, presents a population estimate for the province.

\section{Methods and Study Area}

Each year from 1974-1977 nesting Piping Plovers were censused on a small beach on the east shore of Dowling Lake (henceforth referred to as East Beach), $16 \mathrm{~km}$ north of Hanna, Alberta (Figure 1). In 1975, we measured: a) the width of the beach at the points of nesting along a line perpendicular to the shoreline (this also proved to be the shortest distance from the nest to the water and to the grass mat vegetation), b) the distance between adjacent nests and c) the distance at which incubating plovers flushed from their nests as a result of human intrusions. This latter distance was determined by first locating a suspected plover territory based on the presence of an adult, advancing toward the adult in hopes of flushing a second adult thus indicating the probability of a nest. Retreating to a point where the adult's unhindered return to the nest could be observed, we finally advanced again toward the nest while a second observer watched the incubating bird and noted when it departed. This method was necessary because unless the location of the nest site was known, it was almost impossible to determine when the incubating bird got off its nest.

In June and July 1976 we expanded our census to include the entire shorelines of Dowling Lake, Chain Lakes (NW of Dowling), Third Miquelon Lake and Lowden Lake. These are lakes or lake groups on which Piping Plovers have nested previously. ${ }^{10} 11$ They were censused on foot and/or by boat. 


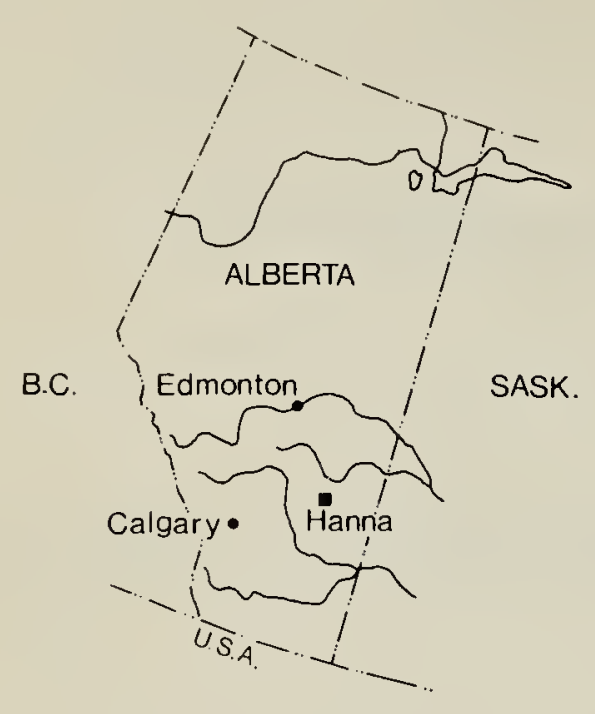

Figure 1. The Dowling-Chain Lake area north of Hanna, Alberta.

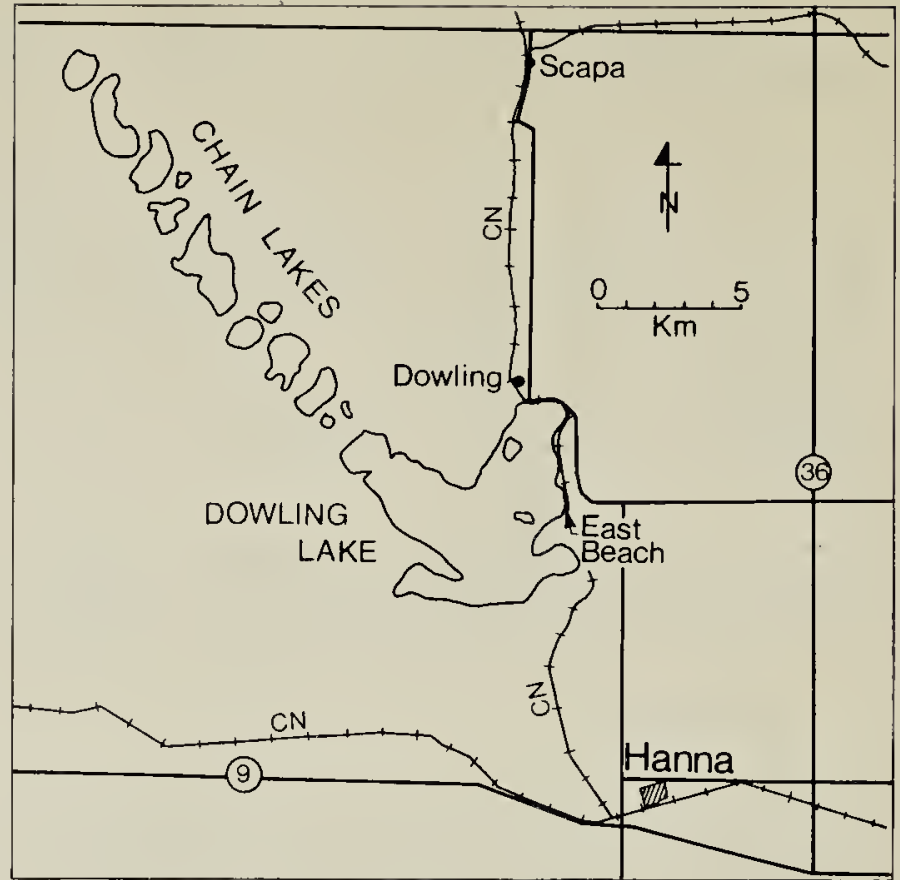

\section{Results}

The results of our work on East Beach are given in Tables 1 and 2 . The length of East Beach was approximately 1000 feet $(300 \mathrm{~m})$ and in 1975 the depth of the beach at the points of nesting ranged from 36-43.5 feet (10.9-13.2 m). From 5 to 10 plovers were present on 3 5 territories during the 4 years (Table 1 ). In 1975 the shortest distance from each nest to the water's edge averaged 28.0 feet $(8.5 \mathrm{~m})$ while the average distance from each nest to the continuous grass vegetation (uphill from the nest) was 10.5 feet (3.2 m; Table 2). The average beach depth at the point of nesting was 38.5 feet $(11.7 \mathrm{~m})$. Incubating birds left their nests on our second approach at an average flushing distance of 154.0 feet $(46.6 \mathrm{~m})$.

The results of the shoreline censuses in 1976 and of other field reports are given in Table 3 . There were 12-15 nesting pairs of plovers on Dowling Lake with the greatest concentration on East Beach and on a long pebble beach point on the extreme west shore. The remaining nests were scattered along the shoreline but primarily on the SE and NE shores. No nesting plovers were observed on either of the two main islands (where gulls nest) in the lake. On 2 of the 6 Chain Lakes, immediately NW of Dowling Lake, a total of 12-15 pairs also were located. The other 4 Chain Lakes were either completely dry or their shorelines were covered by emergent vegetation and were unsuitable nesting areas. On one beach on Buffalo Lake staff from the Provincial Museum observed a single pair and estimated there may have been upwards of 10 pairs of plovers around the very convoluted shoreline of this large lake where they have been reported several times in the past (R. Burns, pers. comm.).

Lastly, from the reports of others, we can trace approximately 22 additional nesting pairs of Piping Plovers in Alberta. Several years ago, Dr. Cy Hampson (formerly Department of Education, University of Alberta) spent 2 summers photographing Piping Plovers at a small unnamed lake near Bashaw. He estimated that there were 10 pairs nesting there each year (pers. comm.). Elsewhere, Kondla and Pinel reported a pair nesting at Goosequill Lake in 1972. ${ }^{13}$ A pair also nested at Namaka Lake during the late 1960 s or early 1970s (? 1973, T. Sadler, pers. comm.). 
Table 1. NUMBER OF INDIVIDUALS AND TERRITORIES OF PIPING PLOVERS ON EAST BEACH, DOWLING LAKE, 1974-1977.

$\begin{array}{ccc}\text { Year } & \begin{array}{c}\text { Number of Piping Plovers } \\ \text { Observed on Territory }\end{array} & \begin{array}{c}\text { Number of } \\ \text { Territories }\end{array} \\ 1974 & 5 & 3 \\ 1975 & 7 & 4 \\ 1976 & 8 & 4 \\ 1977 & 10 & 5\end{array}$

Table 2. SOME CHARACTERISTICS OF PIPING PLOVER NEST SITES ON EAST BEACH, DOWLING LAKE, 1975 and 1976.

\begin{tabular}{|c|c|c|c|c|c|}
\hline Nest & $\begin{array}{l}\text { Nest-water } \\
\text { Distance } \\
\text { (ft.) }\end{array}$ & $\begin{array}{l}\text { Nest-grass } \\
\text { Distance } \\
\text { (ft.) }\end{array}$ & $\begin{array}{l}\text { Beach Width } \\
\text { (ft.) }\end{array}$ & $\begin{array}{l}\text { Flushing } \\
\text { Distance } \\
\text { (ft.) }\end{array}$ & $\begin{array}{c}\text { Inter-nest } \\
\text { Distance } \\
\text { (ft.) }\end{array}$ \\
\hline \multicolumn{6}{|l|}{1975} \\
\hline 1 & 27.0 & 9.0 & 36.0 & 198 & \\
\hline 2 & 25.5 & 10.5 & 36.0 & 126 & 1 to $2=145.5$ \\
\hline 3 & 31.5 & 12.0 & 43.5 & 138 & 2 to $3=259.5$ \\
\hline \multicolumn{6}{|l|}{1976} \\
\hline & $\begin{array}{c}\text { bitat and } f \\
72.0\end{array}$ & ng distance & $\begin{array}{c}t \text { available. } \\
885\end{array}$ & 231 & 1 \\
\hline
\end{tabular}

Table 3. NUMBER OF PAIRS OF PIPING PLOVERS RECORDED (OR ESTIMATED) NESTING AT VARIOUS LAKES IN ALBERTA IN RECENT YEARS

$\begin{array}{lc}\text { Lake } & \text { No. Pairs } \\ \text { Dowling Lake } & 12-15 \\ \text { Chain Lakes } & 12-15 \\ \text { Buffalo Lake } & 10^{1} \\ \text { Unnamed lake near Bashaw } & 10^{1} \\ \text { (Third) Miquelon Lake } & 1-2 \\ \text { Goosequill Lake } & 1 \\ \text { Namaka Lake } & 1 \\ \text { Lowden Lake } & 0 \\ \quad \text { Total } & \text { 47-54 }\end{array}$

' Estimated 


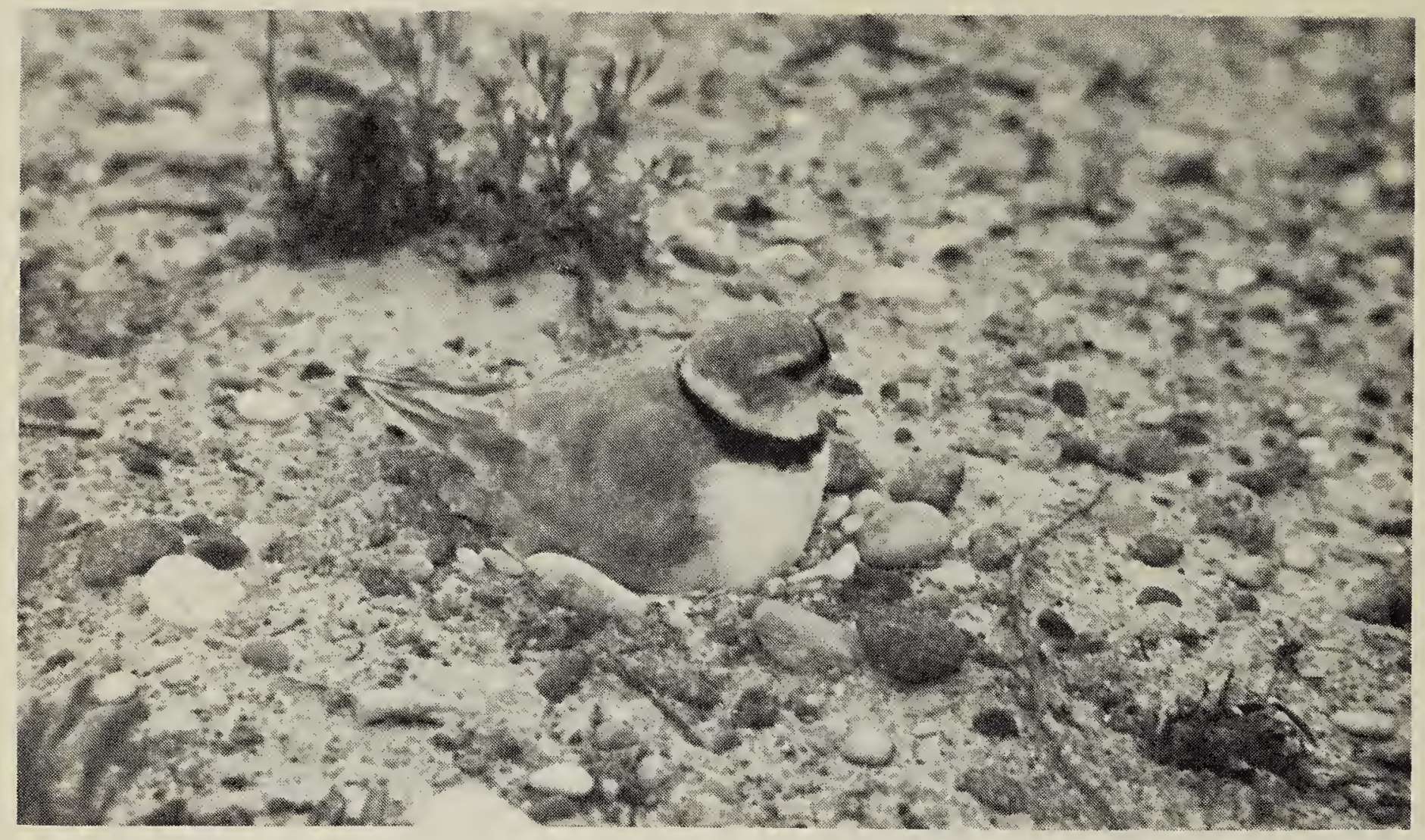

Piping Plover on nest.

G. J. Smith

Assuming a fairly constant population of Piping Plovers at each of these locations each year during the period 1970-1977, there were approximately 47-54 known nesting pairs of Piping Plovers at the above 9 lakes.

Based on the known breeding range of Piping Plovers in Alberta (see below), their general habitat requirements and the number and size of the lakes within their breeding range, we would estimate that these figures account for approximately half of the Alberta population, i.e. during the period of this study we estimate there were 100-110 breeding pairs of Piping Plover residing in Alberta.

\section{Discussion}

\section{Breeding Range in Alberta}

The above nesting records (save one) all fall within the breeding range of the Piping Plover, as it is shown in The Birds of Alberta. ${ }^{21} 22$ We know of only 2 Alberta breeding records outside the area bounded on the north by the North Saskatchewan River, the south by the Bow-South Saskatchewan Rivers, the west by a line from Calgary to Edmonton (No. 2 Highway) and east by Highway 36. The Salts list one record for Gull Lake, to the NW of this area, but as Gull Lake now receives much recreational (boat) traffic, we suspect this site may no longer be active. ${ }^{21}$ The record of Kondla and Pinel from Goose Quill Lake is east of Highway $36 .^{13}$

To the north and west of the above breeding range, the major factor limiting nesting would certainly seem to be the natural unavailability of suitable habitat. Much of the area surrounding Beaverhill, Miquelon and Gull Lakes is transitional from Aspen Parkland to Boreal Forest habitat type. In the Boreal Forest area of Alberta, while there are isolated sand and pebble beaches on several of the lakes, the beaches are probably never of the width required by Piping Plovers. The fact that there are few, if any, sight records of Piping Plovers from this area emphasizes the narrow habitat tolerances of the species. ${ }^{202122}$

The most southerly Alberta nesting record of which we know is from 
Namaka Lake, approximately 5 miles north of the Bow River. During the summer of 1970 Piping Plovers were seen at Little Fish Lake, NE of Namaka Lake, but they are not known to have nested there. ${ }^{13}$ In southern Alberta, south of the Bow-South Saskatchewan Rivers, the lack of breeding records is not easily explained. In this area, approximately south of the Trans-Canada Highway, lie hundreds of square miles of short-grass prairie with multitudes of scattered lakes and potholes - bodies of water which, in many cases, would seem to be ideal nesting habitat for Piping Plovers. However, nesting records are non-existent and there are few sight records for this area of the province. ${ }^{20}$ Sight and nest records from northern Montana, adjacent to Alberta, are also scarce. ${ }^{23}$ We can offer no precise explanation for this lack of nesting in what would seem like ideal habitat; some special feature must be absent (or present) in this area (see below).

In the eastern third of Alberta, east of a north-south line through Hanna to the
Alberta-Saskatchewan border, a distance of nearly 100 miles $(160 \mathrm{~km})$, we know of only one Piping Plover nesting record. ${ }^{13}$ This area has a low human population and future searches may reveal more plovers in this area. Renaud shows nest records of Piping Plovers throughout central-southern Saskatchewan up to the Alberta-Saskatchewan border. ${ }^{17} 18$

\section{Habitat Requirements}

Several authors have alluded to the necessity of wide, deserted beaches as nesting habitat requirements for the Piping Plover. ${ }^{6}{ }^{16}{ }^{19}$ Fortunately on many of the lakes in Alberta, where relatively large numbers of plovers nest, there is little, if any, (present) threat of habitat destruction. By current standards these lakes are too isolated from population centres, too alkaline and too shallow for much recreational development. However, a shoreline park and small boat access were developed on Buffalo Lake prior to this study and reportedly displaced a number of pairs of Piping






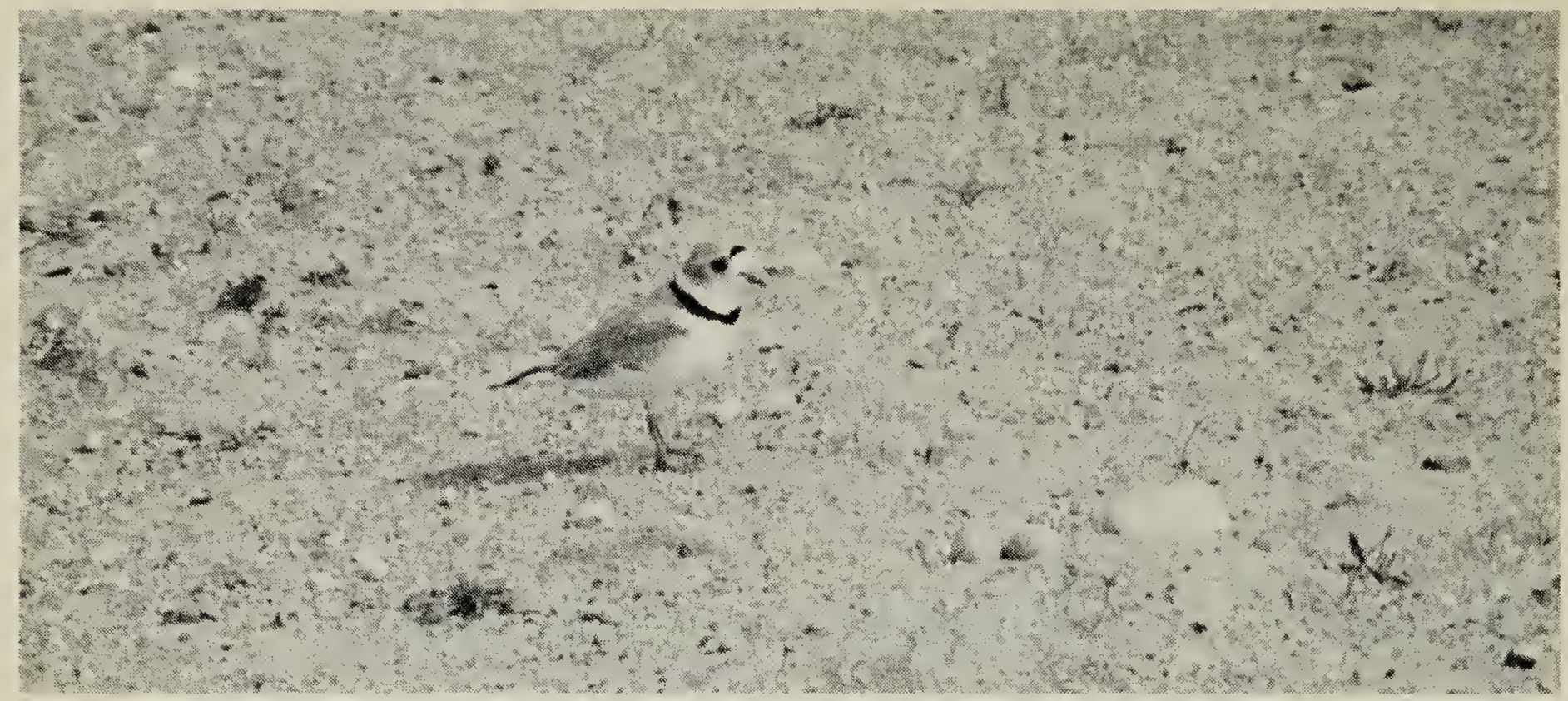

Piping Plover - Manitou Lake, Saskatchewan.

Eileen Graham

Plovers (N. Kondla, C. D. Bird, pers. comm.)!

Concerning beach width, it is unfortunate that we did not measure this feature on beaches (or lakes) that did not support nesting Piping Plovers. On East Beach, the plovers appeared to nest in areas of greatest beach depth. Plovers did nest elsewhere on beaches narrower than those on East Beach but we do not recall finding any on beaches of 5-10 feet $(1.5-3 \mathrm{~m})$ width.

The width of the beach, and hence the area available for territory selection, is dependent upon the water level of the lake. This was illustrated dramatically in 1977 , a very dry year, when the average width of East Beach increased to 183 feet $(55.5 \mathrm{~m})$. This drought quadrupled the available beach and, along with the complete drought of the two Chain Lakes, which held plovers in 1976, may explain the appearance of a fifth pair of plovers on East Beach in 1977.

\section{Stability of Population}

With an estimated provincial breeding population of 100-110 pairs, the stability of the Piping Plover nesting population is very important. From admittedly sketchy, general and word-of-mouth accounts some indication of population stability can be gathered. Salt and Wilk list Miquelon, Buffalo, Gull, Baxter and Beaverhill Lakes as (historical) nesting areas. ${ }^{22}$ Piping Plovers continue to nest at Miquelon and Buffalo Lakes. They do not nest at Beaverhill Lake, though they are occasionally seen there, and we know of no recent records from Gull or Baxter Lakes. The nesting at Namaka Lake seems, at best, to have been irregular. In 1970-72 and 1974-75 visits were made to the very isthmus on which the nest was found, but to no avail. As stated above, Dr. Hampson reported consistent numbers in each of 2 successive years near Bashaw. In July 1970, while the senior author was banding gulls on Dowling Lake, Bill Glasgow showed him his first nesting pairs of Piping Plovers. Glasgow estimated there to be perhaps a dozen pairs nesting around the lake at that time (pers. comm.). The reports of Glasgow and our surveys at Dowling Lake suggest that the population there has been stable at $12 \pm$ pairs for the previous six to seven years.

Thus the picture that emerges is that at what may be the centre of their Alberta range, Piping Plover numbers appear stable. At the edges of their Alberta range, the presence of nesting pairs is not as consistent as at more 
centrally located areas and the numbers of nesting pairs per lake is substantially reduced. Local drought conditions may greatly affect the presence and numbers of nesting pairs but presumably this is only a short term and/or cyclic effect.

\section{Acknowledgements}

Portions of this study were conducted while the senior author was employed by the Provincial Museum of Alberta (PMA). We would like to acknowledge the field assistance of Karen Drysdale (PMA volunteer) and Ludo Bogaert, Jasper Kaiser and Rod Burn (past or present PMA employees). Dr. Cy Hampson kindly provided unpublished data. W. E. Renaud and M. K. McNicholl made comments on earlier versions of this text.

1 ARBIB, R. 1972. The blue list for 1973. Am. Birds 26:932-933.

${ }^{2}$ ARBIB, R. 1974. The blue list for 1975. Am. Birds 29:1067-1077.

${ }^{3}$ TATE, J. Jr. 1981. The blue list for 1981. Am. Birds. 35:3-10.

${ }^{4}$ AMERICAN ORNITHOLOGISTS' UNION. 1957. Check-list of North American birds. Fifth ed. Am. Ornithol. Union. Baltimore, Md. 691 pp.

${ }^{5}$ BELL, F.H. 1978. The Piping Plover (Charadrius melodus Ord) in Canada: a status report. Unpubl. report of Committee on the Status of Endangered Wildlife in Canada. Museum of Natural Science, Ottawa.

${ }^{6}$ CAIRNS, W. E. 1977. Breeding biology and behaviour of the Piping Plover (Charadrius melodus) in southern Nova Scotia. M.Sc. thesis, Dalhousie University, Halifax, 155 pp.

${ }^{7}$ CAIRNS, W. E. and I. A. MCLEAN. 1980. Status of the Piping Plover on the East Coast of North America. Am. Birds 34:206-208.

${ }^{8}$ CARTAR, R. 1976 . The status of the Piping Plover at Long Point, Ontario, 19661975. Ont. Field Biol. 30(2):42-45.

${ }^{9}$ EBEL, G. R. A. and D. A. E. SPALDING. 1975. A preliminary list of Alberta's vulnerable birds, Part II. (Hawks-
Fringillids). Alberta Naturalist 5(4): 112120.

${ }^{10}$ FARLEY, F. L. 1931. Nesting of the Piping Plover in Alberta. Can. Field Nat. 45:2122.

$"$ GODFREY, W. E. 1966. The birds of Canada. Nat. Mus. Can. Bull. No. 203, Biol. Ser. No. 73, Queen's Printer, Ottawa. $428 \mathrm{pp}$.

12 HUSSELL, D.J.T. and R. D. MONTGOMERIE. 1966. The status of the Piping Plover at Long Point, 19601965. Ont. Field Biol. 20:14-14.

${ }^{13}$ KONDLA, N. G. and H.W. PROVEL. 1973. Breeding records of 19 species of birds in southern Alberta. Blue Jay 31:153-157.

${ }^{14}$ LAMBERT, A. and B. RATCLIFF. 1981 Present status of the Piping Plover in Michigan. The Jack-Pine Warbler 59:44-52.

${ }^{15}$ NIEMI, G. J. and T. E. DAVIS. 1979. Notes on the nesting ecology of the Piping Plover. The Loon 51:74-79.

${ }^{16}$ PICKWELL, G. 1925. Some nesting habits of the Belted Piping Plover. Auk 42:326332.

17 RENAUD, W. 1974. Nesting Piping Plover in Saskatchewan. Blue Jay 32:158-162.

${ }^{18}$ RENAUD, W. 1979. The Piping Plover in Saskatchewan: a status report. Blue Jay 37:90-103.

${ }^{19}$ RUBBINS, C. A. 1919. A colony of Cape Cod Piping Plover. Auk 36:351-355.

${ }^{20}$ SADLER, T. S. and M. Y. MYRES. 1976. Alberta Birds 1961-1970. Provincial Museum of Alberta, Natural History Section, Occas. Paper No. 1. Edmonton. $314 \mathrm{pp}$.

${ }^{21}$ SALT. W. R. and J.R. SALT. 1976. The Birds of Alberta. Hurtig Publishers, Edmonton, Alberta. 498 pp.

${ }^{22}$ SALT, W. R. and A. L. WILK. 1966. The Birds of Alberta. 2nd Edition. Queen's Printer, Edmonton. 511 pp.

${ }^{23}$ SKAAR, P.D. 1975. Montana Bird Distribution. P.D. Skaar, Bozman, Montana. 56 pp.

${ }^{24}$ WILCOX, L. 1959. A twenty-year banding study of the Piping Plover. Auk 76:129152. 